\title{
Preferential Treatment of Charities Under the Unemployment Insurance Laws
}

The contributions collected from employers under State unemployment compensation laws are not in the nature of a general tax for general revenue purposes . . . [T] specific purpose. . . If you are going to have a specific premium for this specific purpose, then it is only logical, fair and equitable that each type of enterprise pretty much carry its own unemployment costs. ${ }^{1}$

The Federal Unemployment Tax Act (the "Act") ${ }^{2}$ governs an unemployment insurance program for employees of both nonprofit and forprofit organizations. Federal and state payroll taxes, levied on employers and based on an employer's prior unemployment record, ${ }^{3}$ fund the unemployment insurance program and pay for unemployment compensation benefits. Despite the program's explicit premise that the costs of unemployment are an ordinary and necessary cost of doing business that should be financed by employers, ${ }^{4}$ and the extension of coverage to nonprofit em-

1. Address by Paul A. Raushenbush, Director, Unemployment Compensation Dep't, Industrial Comm'n of Wisconsin (Oct. 21, 1941), reprinted in P. Raushenbush \& E. Raushenbush, OuR "U.C." STORY 1930-1967, at 281, 292-93 (1979).

2. 26 U.S.C. $\S \S 3301-3311$ (1982).

3. See infra notes 16-25 and accompanying text.

4. "The basic justification for using a payroll levy at all, to finance unemployment compensation, is that irregular employment and lay-offs and unemployment are connected with business operations, and that benefit costs should accordingly be treated and assessed as business costs." Raushenbush, supra note 1, at 293. In discussing his approval of the payroll tax on employers, President Franklin Roosevelt stated that "the costs of seasonal and intermittent unemployment . . . [are] a foreseeable loss, the major cost of which ought to be computed and borne like every other cost of a business." Letter from President Franklin Roosevelt to a Congressman (March 23, 1934), in 3 The Public Papers and AdDresses of FrankLin D. Roosevelt 161, 161 (1938) [hereinafter cited as RoOSEvelt PAPERS]; see also Rector, The Frailty of the "Fallacy" of Experience Rating, 2 LAB. L.J. 338, 346 (1951) ("Certainly the cost of industrial unemployment is a production cost . . . .").

Despite this understanding of the purpose and rationale for unemployment taxes, Congress has consistently exempted charities from this regular cost of doing business. See infra text accompanying notes $26-32$. 


\title{
Unemployment Insurance
}

\author{
ployees, ${ }^{5}$ federal law entitles section 501(c)(3) employers ${ }^{6}$ to preferential \\ treatment, effectively subsidizing one of their ordinary business costs. ${ }^{7}$ \\ Given the expansion of the nonprofit sector, ${ }^{8}$ the increasing number of \\ nonprofit organizations that compete with profit-motivated organizations, ${ }^{9}$
}

5. Employment Security Amendments of 1970, Pub. L. No. 91-373, § 104, 84 Stat. 695, 697-99 (amending 26 U.S.C. $\S \S 3303($ e), (f), 3304(a)(6), 3309).

6. I.R.C. $\S 501$ (c)(3) (1982). Section 501 of the Internal Revenue Code exempts only certain nonprofit organizations from the federal income tax. Those exempt under § 501(c)(3) are commonly called charities. Section 501(c)(3) defines these charities as:

[c]orporations, and any community chest, fund, or foundation, organized and operated exclusively for religious, charitable, scientific, testing for public safety, literary, or educational purposes, or to foster national or international sports competition (but only if no part of its activities involve the provision of athletic facilities or equipment), or for the prevention of cruelty to children or animals, no part of the net earnings of which inures to the benefit of any private shareholder or individual, no substantial part of the activities of which is carrying on propaganda, or otherwise attempting, to influence legislation, . . . and which does not participate in, or intervene in (including the publishing or distributing of statements), any political campaign on behalf of any candidate for public office.

For a discussion of possible reasons for this exemption, see infra Part II. Although the income of these organizations is generally tax-exempt, it may be subject to tax under the Unrelated Business Income Tax. See infra note 45.

7. Section 501(c)(3) organizations are exempt from the federal unemployment tax, 26 U.S.C. § 3306(c)(8). In addition, because these employers may choose between two methods of paying for their employees' unemployment insurance coverage, either prepayment of insurance taxes or reimbursement, see 26 U.S.C. \$ 3309(a)(2), they are eligible for deferred payment schedules for the state tax, see infra notes 31 \& 32 and accompanying text.

8. Charitable organizations constitute a rapidly growing and increasingly important sector of the economy. Between 1968 and 1979, the number of $\S 501(\mathrm{c})(3)$ organizations more than doubled, increasing from 137,500 to 293,000. Weisbrod, Assets and Employment in the Nonprofit Sector, 10 Pub. Fin. Q. 403, 412-13 (1982). Although statistics on employment in the nonprofit sector are not precise, and estimates vary, all analysts agree that the nonprofit sector has become an important segment of the total labor force. See Rudney, A Quantitative Profile of the Nonprofit Sector 3-4, 11-17 (Working Paper No. 40, Program on Non-profit Organizations, Institution for Social and Policy Studies, Yale University (November 1981)); Rudney \& Weitzman, Significance of Employment and Earnings in the Philanthropic Sector, 1972-1982, at 7-21 (Working Paper No. 77, Program on Non-profit Organizations, Institution for Social and Policy Studies, Yale University (November 1983)); Sumariwalla, Preliminary Observations on Scope, Size, and Classification of the Sector, in Independent Sector, Working Papers for SpRing Research Forum: Since the Filer Commission 181, 197-200 (1983). A 1974 estimate attributed 5\% of the nation's employment to the nonprofit sector. D. Young, IF NOT FOR PROFIT, FOR WhAT? 9 (1983). Using a slightly different methodology, a 1973 estimate found that nonprofit organizations accounted for $8 \%$ of national employment. Id. In 1977, nonprofit organizations accounted for $1 / 3$ of the employment in the rapidly growing services sector of the nation's economy, employing five times as many people as the automobile industry. L. Salamon \& A. Abramson, The Federal Budget and the NonproftT Sector 12 (1982). In 1980, nonprofit organizations employed an estimated 5.6 million people. Sumariwalla, supra, at 198.

9. The nonprofit sector has expanded in size and changed in character. Hansmann, The Rationale for Exempting Nonprofit Organizations from Corporate Income Taxation, 91 YALE L.J. 54, 57-58 \& nn.16 \& 17 [hereinafter cited as Hansmann, Rationale for Exempting]. Competition between similar for-profit and nonprofit entities has greatly increased, particularly in industries such as hospitals, nursing homes, and schools. See id.; H. Hansmann, The Effect of Tax Exemption and Other Factors on Competition Between Nonprofit and For-profit Enterprise 1-2, 7-8 (Working Paper No. 65, Program on Non-profit Organizations, Institution for Social and Policy Research, Yale University (December 1982)) [hereinafter cited as Hansmann, Effect on Competition]. Often there is little or no difference between the for-profit and nonprofit competitors. See Hansmann, Rationale for Exempting, supra, at 54; Hansmann, The Role of Nonprofit Enterprise, 89 YALE L.J. 835, 862-68 (1980) [hereinafter cited as Hansmann, Role]; see also Clark, Does the Nonprofit Form Fit the Hospi- 
and the growing budget deficit, ${ }^{10}$ preferential treatment of charitable organizations under the unemployment insurance program must be reevaluated.11 A remnant of the traditional special treatment of charities, ${ }^{12}$ this preferential treatment is based on faulty premises, results in for-profit firms' subsidizing the labor costs of charities, and creates unfair and undesirable competitive advantages for charities. Accordingly, Congress should eliminate this preferential treatment of charitable organizations under the Federal Unemployment Tax Act.

\section{Current Status of the Law}

A basic premise of the unemployment insurance program is that unemployment insurance is a regular cost of doing business that employers should finance. ${ }^{13}$ Congress created the unemployment insurance program in the 1930's as an insurance, not as an income transfer, program. ${ }^{14}$ It

tal Industry?, 93 HARv. L. REv. 1416, 1448-71 (1980) (arguing that many traditional rationales for preferential treatment of nonprofit hospitals inadequate for distinguishing between nonprofit and profit-motivated institutions).

10. Although the unemployment insurance program was designed to be self-financing, the statute contains provisions to ensure that unemployed workers receive benefits even if their state's unemployment fund becomes insolvent. State funds can borrow, interest free, from the federal unemployment account. If this account is depleted, advances from general Treasury revenues, in effect interest-free loans, provide financing for the benefits owed. P. MACKIN, BENEFIT FinANCING IN UNEMPLOYMENT Insurance: A Problem of Balancing Responsibiltties 122-24 (1978). In 1975, the federal unemployment account was depleted, bringing into operation the provision for Treasury advances. Funds in the federal extended unemployment compensation account, see infra note 17, were also exhausted, necessitating additional borrowing from Treasury revenues. Id. at 60-61. As of 1978, the Treasury had advanced $\$ 8.7$ billion to the extended unemployment compensation account and $\$ 4.8$ billion to the federal unemployment account. Id. at 124 n.7.

11. A recent U.S. government audit report recommended that Congress revise this preferential treatment. OFFICE OF INSPECTOR GENERAL, U.S. DEP'T OF LABOR, IMPROVEMENTS ARE NEEDED IN THE UNEMPLOYMENT INSURANCE RETMBURSABLE EMPLOYER SYSTEM (1984) [hereinafter cited as 1984 AUDrT REPORT]. The report, however, addressed only some of the practical effects of the unemployment tax exemption, and failed to question the basic rationales underlying the preferential treatment. "The Office of Inspector General . . . made this review to determine the effect the reimbursable employer system has on the interest earnings of the Unemployment Trust Fund, and to determine the effect of reimbursable employers' exemption from paying the [federal unemployment] tax." Id. at 1 .

12. See, e.g., G. Friedman, Unemployment Compensation: What and Why? 41 (U.S. Soc. Security Bd. Publication No. 14, 1937): "Employees of religious, charitable, and educational institutions all could readily come within the compass of an unemployment compensation system but were exempted from the Federal tax on the ground that by established precedent organizations of these kinds are generally exempted from taxes."

13. See supra note 4.

14. President Franklin Roosevelt, the principal champion of the unemployment insurance program, stated, "We must not allow ... [unemployment] insurance to become a dole through the mingling of insurance and relief. It is not charity." F. Roosevent, Address to the Advisory Council of the Committee on Economic Security (Nov. 14, 1934), in 3 Roosevelt PAPERS, supra note 4, at 452,453 . President Roosevelt had already strongly stated his views on unemployment insurance when he was governor of New York:

[Unemployment] relief should not, of course, take the shape of a dole in any respect. The dole

method of relief for unemployment is not only repugnant to all sound principles of social

economics, but is contrary to every principle of American citizenship and of sound government. 
was to be self-supporting, and employees were to feel that they had earned their unemployment compensation benefits. ${ }^{15}$

\section{A. Provisions Governing Non-Charitable Employers}

The Federal Unemployment Tax Act created a federal unemployment insurance program, imposing a federal payroll tax on employers. ${ }^{16}$ Revenue from this tax finances the administrative costs of the unemployment insurance program and some employee benefits. ${ }^{17}$

American labor seeks no charity, but only a chance to work for its living. The relief which the workers of the State should be able to anticipate . . . should be one of insurance . . . .

F. Roosevelt, A Recommendation for a Commission to Investigate Unemployment Insurance (March 25, 1931), in 1 Roosevelt PAPERs, supra note 4, at 455, 456; see also E. BuRNs, Social SECURITY AND PUblic Policy 209 (1956) (proposals for unemployment insurance programs stressed they were not "doles," as British program appeared to be); Malisoff, The Import of Theory in Unemployment Compensation, 55 PoL. SCI. Q. 249, 249 (1940) (unemployment insurance program designed to minimize its resemblance to European systems, which disbursed "doles").

15. The insurance mechanism was seen as an appropriate response to the emotional, as well as economic, strains resulting from unemployment:

The loss of a job brings discouragement and privation to the individual worker and his family.

If an insurance or reserve fund has been accumulated, even a small payment from it at such a

critical time will tide over the worker and keep up his morale and purchasing power.

Letter from President Franklin Roosevelt to a Congressman, supra note 4, at 161 .

A pamphlet issued to explain the new program spoke of the "necessity for a more systematic method of alleviating the suffering caused by unemployment." BUREAU OF UNEMPLOYMENT COMpensation, U.S. Social Security Bd., Circular No. 2, What You Should Know about UNEMPLOYMENT COMPENSATION 2 (1937) [hereinafter cited as What You Should KNOW]. Maintaining the unemployed on "relief" was rejected as "humiliating" and "demoralizing to the recipient and wasteful to the Nation." Id. Stern language emphasized that "[t]he term 'dole' is not applicable to payments of regular unemployment compensation benefits which are payable as a right on the basis of previous payments on behalf of the worker." Id. at 5; see also J. BECKER, UNEMPLOYMENT INSURANCE FINANCING 13, 138 (1981) (self-supporting nature of program and fact that benefits were "earned" were essential to program).

16. Under the Act, every employer must pay an annual federal tax equal to $6.2 \%$ of wages paid for employment covered by the Act. Tax Equity \& Fiscal Responsibility Act of 1982, Pub. L. No. 97248, tit. II, § 271(c)(1), (d)(2), 96 Stat. 324, 555 (amending 26 U.S.C. $\S 3301$ ).

The statute defines an employer to be any person who paid wages of $\$ 1,500$ or more during the present or preceding calendar year, or who employed at least one individual for some portion of at least one day in each of twenty different calendar weeks during the present or preceding calendar years. 26 U.S.C. $\$$ 3306(a)(1) (1982). Separate provisions define employers in the case of agricultural labor, id. § 3306(a)(2), and domestic service, id. § 3306(a)(3). Among the employment excluded from the federal tax is "service performed in the employ of a religious, charitable, educational, or other organization described in section 501(c)(3) which is exempt from income tax under section 501(a)."Id. § 3306(c)(8).

17. In addition to covering the program's administrative costs, the federal tax finances a loan fund, the federal unemployment account. If a state's unemployment account does not contain sufficient funds to cover the state's unemployment compensation obligations, the state's account can borrow, interest free, from the federal unemployment account.

In states with very high unemployment levels, unemployed workers can receive up to 13 additional weeks of "extended benefits," the costs of which are shared by the states and the federal government. The federal tax also finances half of the "extended benefits" paid to unemployed workers who have exhausted their 26 weeks of regular state unemployment compensation benefits. Originally provided only by temporary legislation enacted during prolonged periods of high unemployment, extended benefits became a mandatory and permanent feature of all state unemployment insurance laws in 1970. Federal-State Extended Unemployment Compensation Act of 1970, Pub. L. No. 91-373, § 524, 84 Stat. 695, reprinted as amended as note following 26 U.S.C. § 3304 (1982). Legislation to reduce 
Most employee benefits, however, are financed by state unemployment insurance payroll taxes. ${ }^{18}$ Although all covered employers must pay the federal unemployment tax, only those employees whose state has enacted a program receive unemployment compensation benefits. ${ }^{10}$ The Act contains a tax incentive enabling ${ }^{20}$ states to enact programs satisfying the federal guidelines: ${ }^{21}$ It credits an employer's state unemployment taxes toward the employer's federal unemployment tax obligation for that year. ${ }^{22}$

While the federal unemployment tax rate is the same for all employers, ${ }^{23}$ the state programs all use an experiential state unemployment tax rate. An employer's state tax rate varies according to the employer's past unemployment experience. ${ }^{24}$ Thus, employers with good employment

federal spending for domestic programs severely limited the availability of extended benefits. Omnibus Budget Reconciliation Act of 1981, Pub. L. No. 97-35, § 2401, 95 Stat. 357, 874-76 (amending Federal-State Extended Unemployment Compensation Act of 1970). In February 1985, the extended benefits program was active in only two states, West Virginia and Alaska.

18. State unemployment taxes, which are deposited into the Federal Unemployment Trust Fund, finance all employee benefits except for one-half of the costs of the extended unemployment benefits, and the loans advanced to state unemployment accounts, see supra note 17.

19. See 26 U.S.C. $\$ 3304$ (1982).

20. Fearful of placing employers within the state at a disadvantage relative to employers in other states, each state was reluctant to enact an unemployment insurance program on its own. Malisoff, supra note 14, at 249. Prior to the 1935 federal legislation, only Wisconsin had enacted such a program. W. HABER \& M. MURRAY, UNEMPLOYMENT INSURANCE IN THE AMERICAN ECONOMY 69-70, 74 (1966); P. MACKIN, supra note 10, at 8 n.6. Federal action removed the danger of this competitive disadvantage. E. BuRNS, Toward Social Security 54-55 (1936).

21. The requirements for state unemployment insurance laws are set forth in 26 U.S.C.A. $\S 3304(\mathrm{a})(1)-(18)$ (West Supp. 1984).

22. 26 U.S.C. $\S 3302$ (1982). An employer's total credits toward the federal unemployment tax obligation may not exceed $90 \%$ of the employer's federal unemployment tax obligation. Id. $\S 3302(c)(1)$.

23. The federal unemployment tax rate is set at $6.2 \%$ for all employers covered by the Act. Tax Equity \& Fiscal Responsibility Act of 1982, Pub. L. No. 97-248, tit. II, \& 271(c)(1), (d)(2), 96 Stat. 324, 555 (amending 26 U.S.C. $\S 3301$ ). An employer's federal tax payments vary only according to the amount of the state tax credited toward the federal unemployment insurance tax obligation.

24. The Federal Unemployment Tax Act both authorizes and places certain restrictions on state implementation of these experience rating systems. An employer's state unemployment tax rate may be reduced only on the basis of the employer's prior employment experience. 26 U.S.C. § 3303(a) (1982). Before 1970, an employer could benefit from experience rating provisions only after paying the full tax rate for at least one year. In 1970 Congress amended the statute, permitting states to grant reduced "experience" ratings (but not less than one percent) to new or newly covered employers. Employment Security Amendments of 1970, Pub. L. No. 91-373, § 122(a), 84 Stat. 695, 702 (amending 26 U.S.C. $\$ 3303(\mathrm{a})(3)$ (1954)).

Experience rating serves several important objectives. First, the threat of increases in tax rates provides an incentive for employers to stabilize employment. Second, experience rating equitably allocates unemployment compensation costs among employers: Those responsible for the payment of more unemployment benefits must pay a higher tax. Third, experience rating attempts to ensure that unemployment reserve funds are neither excessive nor inadequate. Fourth, it encourages employers actively to "police" the payment of unemployment compensation benefits, ensuring that they are paid only to those who ought to receive them. J. BECKER, supra note 15, at 66-68, 88-95, 102-05; W. HABER \& M. MURRAY, supra note 20, at 337-46; E. BURNS, supra note 14, at 166; Raushenbush, supra note 1 , at $289-97$; Rector, supra note 4 , at $344-48$. 
records pay lower unemployment taxes than do those who terminate larger numbers of employees. ${ }^{25}$

\section{B. Preferential Treatment of Charities}

Since its enactment in 1935, the Federal Unemployment Tax Act has accorded special treatment to charitable organizations. ${ }^{28}$ The statute presently provides for preferential treatment of any "religious, charitable, educational, or other organization described in section 501(c)(3) which is exempt from income tax under section 501(a) [of the Internal Revenue Code]."27

Prior to 1970, charities paid no unemployment taxes, and their employees received no benefits, unless a state's law provided otherwise. ${ }^{28}$ In 1970 , Congress required the states to extend coverage to the employees of most charitable organizations. ${ }^{29}$ Charities, however, do not have to finance

25. The Act prevents the benefits of the state tax experience ratings from being cancelled out by a comparable increase in the employer's federal unemployment insurance payments. The Act provides that an employer paying less than the state maximum rate may receive a federal credit equal to the amount of tax due under the maximum state rate, up to a maximum credit of $5.4 \%$ of the employer's taxable payroll. Tax Equity \& Fiscal Responsibility Act of 1982, Pub. L. No. 97-248, tit. II, § 271(c)(2), (3)(A), (B), (d)(2), 96 Stat. 324, 555 (amending 26 U.S.C. § 3302(b)). An employer may receive this additional credit only if the state tax reduction was based on the employer's experience rating. 26 U.S.C. $\$ 3303$ (1982).

Since each state now has an unemployment compensation program with experience ratings, the effective federal unemployment insurance tax is $.8 \%$ of taxable payroll. 1984 AUDrT REPORT, supra note 11 , at 5 .

26. Congress has narrowed the exemption in several stages since 1935 . One reason originally given for excluding employees of these organizations from coverage was that the "socially desirable, or supposedly socially desirable activities" of these organizations "should not be hampered by requiring them to be financially responsible for insuring their employees against loss of employment." Gellhorn, The Extension of Coverage of Unemployment Compensation, 23 MinN. L. REv. 173, 174 (1939). Others suggested that charities were exempted simply to follow tradition. See What You Should KNow, supra note 15, at 11; G. FRIEDMAN, supra note 12, at 41 ; Gellhorn, supra, at 174.

27. 26 U.S.C. $\S 3306(c)(8)$ (1982). The preferential treatment applies both to employment performed in the conduct of the organization's primary, exempt activities, and to employment performed in the conduct of its unrelated activities. See Alabama v. Marshall, 626 F.2d 366, 369 (5th Cir. 1980) (employment for church school exempted, because school's employees are employed by church); Rev. Rul. 56-188, 1956-1 C.B. 485 (services performed by exempt organization's employees in the conduct of its unrelated business were exempted from social security taxes, under statutory language almost identical to that of 26 U.S.C. § 3306(c)(8) (1982)).

28. Although extension of coverage to employees of these organizations was not forbidden, there was no federal tax credit incentive to encourage states to do so. Only a few states did provide coverage for these employees. See Murray, Unemployment Insurance: Risks Covered and Their Financing, in IN AId of THE UNEMPLoyed 63, 66-67 (J. Becker ed. 1965).

29. Employment Security Amendments of 1970, Pub. L. No. 91-373, § 104, 84 Stat. 695, 697-99 (amending 26 U.S.C. $\$ \S 3303(\mathrm{e}),(\mathbf{D}), 3304(\mathrm{a})(6), 3309)$. State law coverage of charities is now a condition of federal approval of the state program. See 26 U.S.C. $\S 3304(a)(6)$ (1982). Without fedcral approval of the state program, other employers in the state would be ineligible to receive the federal tax credit for their state unemployment insurance tax payments.

The 1970 Amendments extended state unemployment insurance protection to an additional three million workers in the nonprofit sector. See 33 Soc. SEcurity BulL., Nov. 1970, at 30. Under current law, charities employing fewer than four employees still need not be covered. 26 U.S.C. $\S 3309$ (c) (1982). The other major groups excluded from mandatory state coverage are employees of 
this coverage through the traditional unemployment tax. They remain exempt from the federal tax ${ }^{30}$ and federal law gives them the choice of reimbursing the state for any benefits paid to the organization's employees ${ }^{31}$ or paying the state unemployment insurance payroll tax, as other employers are required to do. ${ }^{32}$ Under either method of payment, the employees of charitable organizations receive the same unemployment compensation benefits as do employees of for-profit organizations, but at less cost to their employer.

Preferential treatment under the Federal Unemployment Tax Act creates several different financial benefits for section 501(c)(3) employers. ${ }^{33}$ First, these employers need not pay the federal tax, which covers the administrative costs of the program. ${ }^{34}$ Second, section 501(c)(3) employers save significantly on labor costs because their deferred payment schedule-reimbursing the state rather than prepaying-reduces their unemployment insurance costs. ${ }^{35}$ Furthermore, reimbursement payments are

churches and of state or local governments. 26 U.S.C. $\$ 3309$ (b) (1982).

30. See 26 U.S.C. $\$ 3306(c)(8)(1982)$.

31. 26 U.S.G. $\$ 3309$ (a)(2) (1982) (state unemployment insurance programs must allow $\S 501$ (c)(3) employers to elect "to pay (in lieu of such contributions) into the State unemployment fund amounts equal to the amounts of compensation attributable . . . to such service"). State law may regulate the time at which the option to elect reimbursement must be exercised, may set a minimum period for such election to be in effect, and "may provide safeguards to ensure that . . organizations so electing will make the payments required under such elections." Id. Although over 20 states provide authority for the state unemployment commissioner to implement such safeguards, only a few actually have. 1984 AUDIT REPORT, supra note 11, at 22-23 (noting the lack of safeguards and urging that security deposits be required by federal law).

32. Charitable employers that choose to pay the unemployment insurance payroll tax are subject to the same state tax rates, determined by their past employment record, as other employers in that state. See 26 U.S.C. $\$ 3309$ (a) (1982).

33. The total value of the federal exemption of $\S 501$ (c)(3) organizations from the unemployment insurance tax may be over a quarter of a billion dollars. An employer who is eligible to receive the full 5.4\% state payment credit toward the federal unemployment insurance tax obligation will owe a federal unemployment insurance tax equal to $.8 \%$ of the first $\$ 7,000$ of wages paid to each employee, see supra note 25 , or $\$ 56$ annually for each employee. Section 501(c)(3) organizations presently employ 5.3 million workers. See H.R. REP. No. 25, 98th Cong., 2d Sess. 15, reprinted in 1983 U.S. Code Cong. \& AD. News 219,233 . If all of them earned at least $\$ 7,000$, the uncollected federal unemployment insurance tax alone would be worth about $\$ 290$ million annually.

34. See 26 U.S.C. $\$ 3306(c)(8)$ (1982). The recent audit report calculates that $\$ 40$ million annually is "a conservative estimate of the total administration costs associated with reimbursable employers, but borne by contributory employers." 1984 AuDIr REPORT, supra note 11, at 28. This estimate includes the administrative costs of covering state and local government employees, as well as those of charitable organizations. The estimate was not adjusted to account for the fact that "reimbursable benefits probably incur more than an equal share of administration costs" because of the separate accounting and billing systems required. Id. at 29. The figure also does not include expenses of other programs financed by the federal unemployment tax. Id. at 28-29.

35. The present value of a future debt obligation decreases as the payment is deferred farther into the future. See, e.g., A. Alchian \& W. Allen, University Economics 204 (2d ed. 1968).

Charitable organizations save not only because they do not pay in advance, but also because state repayment requirements are very lenient. 1984 AUDIT REPORT, supra note 11, at 12-16. Extended billing schedules enable these employers to borrow from the unemployment tax payments of for-profit employers, resulting in an unfair tax burden on the for-profit employers. Id. at 3. The state's loss of investment income from "borrowed" funds costs millions of dollars annually, an estimated $\$ 37$ million 
likely to be less than regular payroll contributions would have been, ${ }^{36}$ thus reducing the reimbursing employer's costs even more. Finally, deferring reimbursement until a time when the employer can perhaps least afford it-when financial straits have led to personnel reductions $^{37}$ - means that in practice many section 501(c)(3) employers may never pay the costs of unemployment compensation. ${ }^{38}$ The unemployment insurance costs of a section 501(c)(3) organization that fails to reimburse the state's fund will be borne by other employers who have paid their taxes regularly. ${ }^{38}$

\section{The Faulty Premises for Preferential Treatment of Gharitable Organizations}

Two particular considerations led Congress to continue preferential treatment of section 501(c)(3) organizations, when, in 1970, it extended unemployment insurance coverage to their employees. First, Congress did not want to change these organizations' tax exempt status. ${ }^{40}$ Second, Congress expressed a desire to avoid having nonprofit organizations fund unemployment costs attributable to profit-motivated employers. ${ }^{11}$ Neither of

in 1982. Id. at 1, 3, 11-12; see also id. at 21 ("Until reimbursable employers are under an advance payment system, an already insufficient Unemployment Trust Fund will continue to lose millions of dollars of interest earnings annually due to contributory employers' tax dollars being used to finance reimbursable benefits.").

36. Because of an increased experiential tax rate, an employer paying the state payroll tax will often pay considerably more than what the former employee received in benefits. See Payroll Tax Savings, 1B UNEMPL. INS. REP. (CCH) I 24,031 (Aug. 22, 1973) (example illustrating what benefit charges can cost in taxes).

37. Prepayment of unemployment insurance costs, ensuring that an employer paid when he could best afford it, was one of the benefits of the program as originally designed. Such a program would tend to alleviate the pressure to raise funds during times of depression when money was most scarce. See G. FRIEDMAN, supra note 12, at 8. As the program's advocates noted, "[i]t is practical sense to build a system which will gather the funds in good times and disburse them in bad times. This simple theory underlies all formal proposals for unemployment insurance . . . King, Unemployment Reserves and Insurance, 23 AM. LAB. LEGIS. REv. 170, 170 (1933), quoted in G. FrIEDMAN, supra note 12 , at 1 .

38. An employer who dismissed an employee because the organization lacked funds or closed down might well find it difficult to reimburse the state's unemployment compensation funds promptly, completely, or even at all. Those who opposed the reimbursement program claimed that the difficulties of reimbursement posed a significant risk in the case of charitable organizations. They argued that "most unemployment in nonprofit organizations results from budget shortages or closing of institutions." Murray, supra note 28, at 67. Thus, creation of a reimbursement program option was particularly inappropriate for charitable organizations.

39. The 1984 Audit Report recommends changing the reimbursement option to an advance payment option, billing $\S 501(\mathrm{c})(3)$ employers for the "average monthly or quarterly benefit charges based on the employer's most current benefit payment history," charging interest if the employer's payments are consistently lower than the unemployment costs attributed to that employer. $1984 \mathrm{AU}$ DIT REPORT, supra note 11, at 17-18 (emphasis in original). Responding only to the practical problems of financing, this solution does not question the validity of different treatment of charities.

40. S. Rep. No. 752, 91st Cong., 2d Sess., reprinted in 1970 U.S. Code Cong. \& AD. News $3606,3618$.

41. Id. Concern that charitable organizations not be required to accumulate unnecessary reserves 
these considerations, however, justifies the preferential treatment accorded to charities under the Federal Unemployment Tax Act.

\section{A. Maintaining the Charities' Tax Exempt Status}

Federal income tax principles and exemptions neither dictate nor support the preferential treatment of section 501(c)(3) organizations under the unemployment insurance program.

\section{The Analogy to the Legitimacy of the Income Tax Exemption}

Professors Bittker and Rahdert argue that the exemption of charities from income taxation results from a proper application of generally accepted principles of income taxation. ${ }^{42}$ In their view, income tax liability cannot be assessed for charitable organizations because one can determine neither the charity's taxable income ${ }^{48}$ nor an appropriate tax rate for charities. ${ }^{44}$ Nothing in this logic of exempting section 501(c)(3) organiza-

during their first few years of coverage, before experience rating would take account of their low unemployment rates, may have influenced the decision to allow the reimbursement option. See Murray, supra note 28, at 67 (discussing reimbursement propasals). The same amendments that extended coverage to employees of $\S 501$ (c)(3) organizations, however, also permitted states to grant reduced "experience" ratings to new employers. Employment Security Amendments of 1970, Pub. L. No. 91 $373, \S 122(\mathrm{a}), 84$ Stat. 695, 702 (amending 26 U.S.C. $\S 3303(\mathrm{a})(3)$ ). The goal of preventing unnecessary build-up of reserves could thus have been accomplished without the unemployment tax exemptions.

42. Bittker \& Rahdert, The Exemption of Nonprofit Organizations from Federal Income Taxation, 85 YALE L.J. 299, 357-58 (1976): "The exemption of nonprofit organizations from federal income taxation is neither a special privilege nor a hidden subsidy. Rather, it reflects the application of established principles of income taxation to organizations which . . . do not seek profit."

43. Bittker and Rahdert view the computation of a charity's taxable income as "a conceptually difficult, if not self-contradictory task." Id. at 307. First, it is unclear whether donations should be excluded from income under I.R.C. $\$ 102$ (1982). Id. at 308. Second, even if gross income could be calculated, they argue that current tax rules for determining taxable income are inappropriate for charities. Id. at 309-14. For example, the concept of deducting "ordinary and necessary" business expenses, I.R.C. $\S 162$ (1982), presumes a profit motive, which is obviously not present for charitable organizations. Id. at 309-12. Finally, Bittker and Rahdert suggest that charities may be thought of as conduits for gifts from donors to beneficiaries. As a conduit, the charity itself would have no income for tax purposes. Id. at 312-13, But see infra note 51 and accompanying text (argument that income tax for charities is possible).

44. An appropriate tax rate would be determined in accordance with either the "benefit" or the "ability to pay" theories of taxation. See, e.g., R. Musgrave \& P. Musgrave, Public Finance in Theory AND PRACTICE 227-28 (4th ed. 1984) (summarizing these two basic theories). Bittker and Rahdert argue that the determinant of a charitable organization's tax rate should be the organization's ultimate beneficiaries' ability to pay, since the burden of the tax falls on them. Bittker \& Rahdert, supra note 42 , at 315 . The appropriate tax rates should therefore ideally be determined by imputing the organization's income to these beneficiaries and taxing it at their individual tax rates. Id. Because the recipients can rarely be identified in advance, this is not a practical option. Alternatively, the organization could be taxed, as a surrogate for the ultimate recipients, at the average tax rate that these individuals would have paid. Id. Bittker and Rahdert view computation of this average as presenting insurmountable difficulties. Id. at 315-16.

Elsewhere, Bittker suggests that if the purpose of an income tax is to enable the government to use individual profit to finance the provision of public goods, taxation of charitable organizations is inappropriate. Bittker, Accounting for Federal "Tax Subsidies" in the National Budget, 22 NAT'L TAx 
tions from federal income taxation, however, requires exempting them from unemployment insurance taxes. The unemployment tax, which is levied regardless of whether the employer has any taxable income at all, does not diminish or compromise the employer's exemption from the income tax. The two taxes are unrelated. The income tax, revenues from which finance general public goods, varies according to a progressive rate schedule and is imposed on income, which, according to Bittker and Rahdert, cannot be defined or measured for nonprofit organizations. In contrast, the unemployment tax imposes a uniform tax rate on a measurable component of an employer's production costs. It finances a discrete component of an employer's production costs, not a public good. The ease of calculating an employer's taxable wage base or an equitable tax rate does not change simply because an employer is nonprofit rather than forprofit.

Congress itself has in effect recognized that maintaining the income tax exemption does not require, nor do the principles underlying it justify, a blanket exemption of tax-exempt organizations from all other taxes. They are subject, for example, to the Unrelated Business Income $\operatorname{Tax}^{45}$ and to Social Security taxes. ${ }^{46}$ In fact, despite the special treatment, since 1970 the federal government has effectively imposed an unemployment tax, collected by state governments, on section 501(c)(3) employers. ${ }^{47}$ Finally, the

J. 244, 255-56 (1969). The charity cannot be said to have profits in the generally understood sense of the word, because none of the organization's income can accrue to the benefit of any individual in control of the organization. $I d$.

45. I.R.C. $\$ \S 511-515$ (1982). Under I.R.C. $\S 511$, organizations described in $\S 501$ (c) and exempted from taxation by $\S 501$ (a) must pay a corporate income tax on their unrelated business income. The terms "unrelated business taxable income" and "unrelated trade or business" are defined in $\S \S 512$ and 513 , respectively.

The legislative history accompanying the enactment of the Unrelated Business Income Tax noted, "In fact it is not intended that the tax imposed on unrelated business income will have any effect on the tax-exempt status of any organization." S. REP. No. 2375, 81st Cong., 2d Sess., reprinted in 1950 U.S. Code Cong. \& AD. News 3053, 3081.

While the taxable income from the unrelated business, unlike that from the charity's exempt business, can be calculated, Bittker and Rahdert argue that, for the unrelated as well as the primary, exempt business, one cannot properly determine the appropriate tax rate, consistent with ability-topay principles. Bittker \& Rahdert, supra note 42 , at 325 .

46. Prior to 1983, the Social Security Act provided that employment covered by the Act did not include "service performed in the employ of a religious, charitable, educational, or other organization described in section 501(c)(3) . . . which is exempt from income tax under section 501(a)." 26 U.S.C. $\S 3121$ (b)(8)(B) (1982), repealed by Social Security Amendments of 1983, Pub. L. No. 98-21, $\S 102$, 97 Stat. 65, 70-71. Employees of $\S 501$ (c)(3) organizations could receive social security coverage only if their employer waived the social security tax exemption. A charitable organization could terminate the waiver, and thus the social security coverage of its employees, by giving two years advance notice of its desire to do so. Having once terminated coverage in this fashion, a $\S 501$ (c)(3) employer could not again provide social security coverage for its employees. 26 U.S.C. $\$ 3121(\mathrm{k})(1982)$. Concerned by a growing trend among nonprofit employers to terminate the coverage, H.R. REP. No. 25, supra note 33, at 16-17, Congress repealed the exemption. Social Security Amendments of 1983, Pub. L. No. 98-21, § 102, 97 Stat. 65, 70-71 (amending 26 U.S.C. § 3121).

47. 26 U.S.C. $\$ \S 3303(\mathrm{e}), 3309$ (1982). The preferential treatment simply results in a different amount paid at a different time. 
unemployment tax exemption is not granted to all tax-exempt organizations, but only to those which are tax-exempt under section 501(c)(3), ${ }^{48}$ further indicating that imposition of the unemployment tax is not consistent with the income tax exemption of these organizations.

The structure of the unemployment tax itself also does not compel the preferential treatment of charities. The only practice consistent with the principles of the unemployment tax would be a straightforward application of the statutorily determined tax rates to all employers whose employees are covered by the program. The savings that accrue to charities as a result of their exemption from federal tax under the Federal Unemployment Tax Act thus constitute a subsidy to these organizations. In addition, the state tax reimbursement option completely transforms the charity's state unemployment tax payments from an insurance fee, an ordinary and necessary cost of doing business, to a payment resembling a fine imposed on the employer for dismissing a worker. ${ }^{48}$ Not only is the preferential treatment of charities not mandated by the principles of unemployment insurance taxation, it is completely contrary to one of the primary tenets of the program-that unemployment insurance is a cost of doing business.

\section{The Analogy to the Income Tax Exemption as a Subsidy}

If an exemption from a particular tax is inconsistent with the principles underlying that tax, the exemption may properly be viewed as a tax expenditure, a subsidy. ${ }^{50}$ If one could measure the income of a section $501(c)(3)$ organization, ${ }^{51}$ then the section $501(c)(3)$ income tax exemption

48. The Federal Unemployment Tax Act's preferential treatment of $\S 501$ (c)(3) organizations does not apply to organizations that are exempt from the federal income tax under any of the 22 other subsections of $\S 501$ (c), or under $\S \S 501$ (d) or 401(a). See 26 U.S.C. $\S 3306(c)(8)$ (1982) (defining the exemption in terms of $\S 501$ (c)(3)).

49. The annual assessment of unemployment taxes reinforces the character of the tax as an "extension of the wage system," a regular cost of production. If this tax is not paid at the time the employee produces goods or services, but rather only after he or she is laid off, the program loses one of its essential characteristics. The tax is no longer a part of wages paid for services rendered; instead, it resembles wages that must be paid to an employee who is no longer providing any services.

50. A tax expenditure is a departure from basic tax principles which results in a subsidy paid to the beneficiary. As Professor Surrey explains, the federal income tax rules consist of two types of provisions: those tax rules that "constitute the basic structure of the income tax itself and hence are integral to having such a tax at all," and those which are "special provisions representing Government expenditures made through the income tax system to achieve various objectives apart from that tax." S. Surrey, Pathways to Tax Reform 7 (1973). The latter group, consisting of special exemptions, deductions, credits, and preferential tax rates, effectively provides the beneficiaries of those rules with federal monetary assistance. Surrey argues that tax revenue foregone because of tax expenditures should be regarded in the same way as direct governmental expenditures and thus should be recognized as a subsidy.

51. Professor Hansmann asserts that the taxable income of a charitable organization can in fact be calculated in a manner consistent with income tax principles. Hansmann, Rationale for Exempting, supra note 9, at 59-62.

Although state law definitions of what constitutes a nonprofit organization vary quite widely, Professor Hansmann suggests that the identifying characteristic of nonprofit organizations is that they are 


\section{Unemployment Insurance}

could itself be viewed a subsidy. The reasons advanced to justify the income tax subsidy, however, do not extend to the unemployment tax.

The strongest explanation of the charitable income tax exemption focuses on the exemption's historical development and the traditionally "public service" nature of charities. ${ }^{52}$ This public policy rationale suggests that charitable organizations are properly subsidized because many charities serve a quasi-governmental function, providing goods or services that the government would otherwise have to provide. Taxing the "profits" of a charitable organization in order to finance the government's provision of public goods would therefore be counter-productive as well as inherently contradictory. In allowing the charities to retain their funds instead of paying taxes, the government enables them to provide more services, and thus saves itself money. ${ }^{\text {ss }}$

Subsidizing charities under the unemployment tax, while consistent with this theory of income tax subsidy, is not mandated by the theory: Imposition of the unemployment tax would not undermine the validity or diminish the value of the income tax exemption. Furthermore, the unemployment tax exemption is not an effective mechanism for subsidizing charities. First, the particular factor cost selected is not related to any subsidy goal. Subsidizing the firm's unemployment insurance costs ties the value of the subsidy to the number of employees and to the level of their

subject to a "nondistribution constraint." Hansmann, Role, supra note 9, at 838 . The term refers to the Internal Revenue Code's language prohibiting nonprofit organizations from distributing profits to individuals exercising control over the organization. I.R.C. § 501(c)(3) (1982). In Hansmann's view, this constraint constitutes an essential characteristic of nonprofit organizations. Nonprofit organizations tend to operate in areas of the economy where there is a "contract failure." In these areas, patrons are unable to measure the quality or even the actual provision of the good purchased. They therefore require the additional legal assurance provided by the non-distribution constraint. See Hansmann, Role, supra note 9, at 843-45. The non-distribution constraint assures patrons who donate to or purchase from the nonprofit organization that their contributions or payments fund only the desired service.

Professor Hansmann classifies nonprofits into two categories, commercial and donative. Hansmann, Role, supra note 9, at 840-41. For commercial nonprofit organizations, those whose funding comes from sales of goods or services that they produce, the method of computing taxable income could be the same as that which is applied to a for-profit firm. The tax "would effectively be levied on the sum of (1) earnings saved for expenditure in future years, and (2) net capital investment (i.e. the excess of expenditures on capital equipment over depreciation allowances)." Hansmann, Rationale for Exempting, supra note 9, at 59-61 (footnote omitted).

Taxable income can also be calculated for donative nonprofit organizations, those which receive a substantial portion of their income from donations. Again, the organization's taxable income would be its retained earnings, that part of the income, whether from donations or other sources, which exceeds the organization's expenditures on goods and services. Id. at 61-62.

52. See, e.g., B. Hopkins, The Law of Tax Exempt Organizations 1-8 (4th ed. 1983); Houck, With Charity For All, 93 YALE L.J. 1415, 1421-25 (1984). The nature of organizations in the charitable sector, however, has changed dramatically in recent years. See sources cited supra note 9 (discussing changes in composition of charitable sector).

53. See, e.g., B. Hopkins, supra note 52, at 5; Houck, supra note 52, at 1424; H.R. REP. No. 1860, 75th Cong., 3d Sess., reprinted in 1939-1 (Part II) C.B. 728, 742. But see Hansmann, Rationale for Exempting, supra note 9, at 66-71 (concluding that this rationale is unsatisfying). 
salaries, ${ }^{54}$ rather than to a factor relevant to some social or governmental objective, such as the firm's efficiency or level of charitable activities. ${ }^{.5}$

Second, significantly different groups bear the burden of paying for these two subsidies. The federal income tax applies progressive tax rates to a broad tax base, generating revenues for public purposes. In contrast, the unemployment tax is a more narrowly based tax, imposed only on certain employers in order to provide a benefit specifically for their employees. It is effectively part of the wages an employer must pay. To the extent that the burden of an employer's payroll tax is in fact passed on to the employees, ${ }^{58}$ the unemployment insurance subsidy for charitable organizations is financed by a regressive tax, borne more heavily by employees in labor-intensive, low-wage industries. ${ }^{57}$ In addition, some of the employers who must bear the cost of this subsidy compete with the nonprofit beneficiaries of the subsidy. ${ }^{88}$ The preferential treatment thus creates situations where a for-profit firm must help subsidize its nonprofit competitors by paying a portion of their labor costs. ${ }^{59}$

54. Because the tax is imposed only on the first $\$ 7000$ paid to each employee, 26 U.S.C. $\$ 3306$ (b) (1982), the cost of unemployment insurance as a percentage of total payroll is higher for firms with many lower-salaried employees than for those firms in high-salary industries. The subsidy resulting from the preferential treatment is thus worth more to low-wage or labor-intensive firms. No one has established a correlation, however, between those factors and the production of goods that society desires to subsidize.

55. To the extent that the value of the subsidy is tied to the employer's employment record, the subsidy is directed at promoting a social objective, maintaining stable employment.

56. See D. Hamermesh, Jobless PAy AND THe Economy 10-14 (1977) (suggesting that perhaps half of tax burden is borne by employees); see also U.S. Cong. BudGeT OFFICE, BACKGround PAPER No. 15, UNemployment Compensation: A BACkground RePort 16-17 (1976) (citing study concluding that burden of employer's social security payroll tax is shifted to employee, and suggesting that same shift of tax burden might be expected for unemployment insurance tax, but noting that analogy is not precise); $c f$. G. Break \& J. Pechman, Federal Tax Reform 105-06 (1975) (major share, if not all, of burden of employer's social security payroll tax is eventually borne by employees).

57. See D. HAMERMESh, supra note 56, at 14. Because the unemployment insurance tax, like the social security tax, applies to wage income only up to a certain ceiling, "the incidence of the tax is . . . regressive above that level. The ceiling in fact inverts the principle of income tax exemption by allowing such an exemption at the top rather than at the bottom of the scale." R. MUSGRAVE \& P. Musgrave, supra note 44, at 507; see also G. Break \& J. Pechman, supra note 56, at 106-07 (noting regressive effect of social security payroll tax).

58. See Hansmann, Effect on Competition, supra note 9, at 2.

59. This may further aggravate unfair competition. See infra Part III.

During the early years of unemployment compensation, when employees of charitable organizations were not covered, one author noted that "a distinction should be drawn . . . between taxation for general revenue purposes and 'taxation' for a specific protective use" and suggested that "[w]hile it may be deemed desirable to subsidize. . . [these] institutions, it is doubtful that the subsidy should be at the expense of their employees." Gellhorn, supra note 26 , at 174 n.3.

The subsidy is no longer provided at the expense of these organizations' employees, but one may now question whether such a subsidy, if it is desirable, should be financed only by other employers, some of whom compete with the subsidy's recipients, see supra note 9, or by society as a whole, through general tax revenues. See also Note, The Federal Unemployment Tax Act and the Taxation of Religious Institutions, 15 LAND \& WATER REv. 671, 698 (1980) (suggesting that "Ii]f . . . one keeps in mind the purpose the tax actually serves," extending unemployment tax obligation to religious institutions is not unthinkable). 


\section{The Capital Constraint Argument}

Another possible justification for the income tax subsidy, suggested by Professor Hansmann, ${ }^{B 0}$ is that the subsidy compensates for the constraints on capital formation ${ }^{61}$ faced by nonprofit organizations. Even if the section 501(c)(3) income tax exemption is an appropriate subsidy, however, the unemployment tax exemption is not. The theory justifying the former does not also justify the latter.

The income tax exemption responds directly to the nonprofit organization's need for capital: Subsidy mechanism and subsidy goal are closely linked. Because nonprofit organizations face severe constraints on capital formation, their net earnings are essential sources of capital for expansion. These earnings reserved for future expansion, however, are precisely the organization's "taxable income," as Hansmann defines it. ${ }^{62}$ Imposing the income tax, then, would "cut retained earnings roughly in half, and hence would further cripple a group of organizations that is already capitalconstrained." capital formation.

The timing of the income tax subsidy is also closely linked to the goal of eliminating constraints on capital formation. Hansmann notes that income taxes would not be a cost for nonprofit firms that have reached their equilibrium point of development because such firms do not need to produce profits for equity owners. ${ }^{64}$ At equilibrium, the charity would be spending all its income on present production, rather than retaining profits for equity owners or for future expansion. With annual receipts equal to expenditures, including the costs of capital depreciation, the nonprofit firm would have no retained earnings, and thus no taxable income. ${ }^{65}$ Ex-

60. Hansmann, Rationale for Exempting, supra note 9, at 72-75.

61. The nondistribution constraint, see supra note 51 , makes it more difficult for nonprofits to raise capital. Because of the nondistribution constraint, nonprofit organizations cannot issue ownership shares, and thus do not have access to equity capital. They are limited to debt, donations, and net carnings as sources of capital. Hansmann, Rationale for Exempting, supra note 9, at 72 . In addition, the cost of debt capital may be higher for nonprofit organizations than for for-profit organizations. See Rose-Ackerman, Unfair Competition and Corporate Income Taxation, 34 STAN. L. Rev. 1017, 1029 (1982) (noting that lenders might charge higher interest rates to nonprofit organizations "because lenders have difficulty monitoring the nonprofits' behavior").

62. Hansmann, Rationale for Exempting, supra note 9, at 59-62; see also supra note 51.

63. Hansmann, Rationale for Exempting, supra note 9, at 74.

64. Hansmann explains:

[T]here will be no tax liability for a nonprofit firm that is not growing, but rather is spending all of its income to cover the costs of capital depreciation and variable costs such as wages. . . . Thus, income taxes are not a cost to nonprofit firms in equilibrium . . .

On the other hand, subjecting nonprofit firms to income taxation will have an indirect effect on the behavior of the firms. Since such a tax is effectively a tax on retained earnings, it will reduce the rate at which a nonprofit firm can expand . . . [as well as] the aggregate amount of service that is produced at equilibrium.

Id. at 79-80 (emphasis in original).

65. See supra note 51 . 
emption from the income tax would then cease to provide a subsidy. The income tax exemption is thus not a subsidy paid to nonprofit organizations at all times. Rather, it is a subsidy given only to those nonprofit organizations that have not yet reached their equilibrium level of production, and that therefore require capital for expansion. The unemployment tax exemption, however, subsidizes the charity even after it reaches its equilibrium level of production, and no longer has need for expansion capital.

In sum, imposing the unemployment tax on charitable organizations would not impair the charitable income tax exemption subsidy. Preferential treatment under the Fecieral Unemployment Tax Act is not an efficient mechanism for subsidizing the production of public goods, nor is it tied to the goal of alleviating capital constraints. While the income tax exemption removes what would otherwise be a penalty on saving for future expansion, the unemployment tax exemption simply lowers one of the firm's factor costs. The unemployment insurance program's preferential treatment of charitable organizations is not dictated by principles of income taxation nor by those of unemployment taxation. In fact, it deviates from the basic tenets of the tax. In the process, it creates a subsidy that is not well-tailored to any rational goal.

\section{B. Preventing Charities from Subsidizing For-profit Employers}

Congress was understandably concerned that charitable organizations, many of which are financed by donations, not share in the costs of providing unemployment compensation benefits to the employees of profitmaking firms, ${ }^{B B}$ and it thus sought to create a self-insurance program for nonprofit employers. ${ }^{87}$ The preferential treatment accorded charities was not necessary, however, to avoid the subsidization of profit-making enterprises by charitable organizations. The basic structure of the unemployment tax, which provides for experiential state tax rates, ${ }^{88}$ was specifically designed to minimize, if not eliminate, the extent of any transfer between employers. Although neither program ensures that an employer pays only those costs attributable to his or her employees, unemployment compensation, like social security, is considered to be an "earned" benefit, not wel-

66. The Senate Report does not elaborate on this explanation for the preferential treatment accorded $\S 501$ (c)(3) organizations, stating only that "[t]he committee considers it appropriate that these organizations, which are often dependent upon charitable contributions, should not be required to share in the costs of providing benefits to workers in profit-making enterprises." S. REP. No. 752, supra note 40, reprinted in 1970 U.S. CoDE CONG. \& AD. NEwS, at 3618.

67. Id.

68. See supra notes $24 \& 25$ and accompanying text. 
fare. In theory, then, each employee receives back from the system that which was contributed on his or her behalf in the first place.

As in any insurance program, there may be some slight transfer of funds from one payor to another. It is thus possible that there could be some transfer from charitable organizations to for-profit firms. The fact that the social security program no longer distinguishes between charitable and non-charitable employers ${ }^{69}$ indicates, however, that it does not contradict social policy to allow the possibility of such a transfer as a result of a program that creates a public good. In fact, the social security program creates a greater potential for the transfer of nonprofit funds to for-profit firms, because the social security program operates as an intergenerational transfer. ${ }^{70}$ Any slight cross-subsidy that might result from imposing the unemployment insurance tax on charitable organizations is comparatively insignificant.

If there is some transfer, the Federal Unemployment Tax Act's exemptions are not well-tailored to prevent it. First, although Congress seemed to be concerned only with organizations that rely on donations for their support, ${ }^{71}$ all section 501(c)(3) organizations receive preferential treatment, ${ }^{72}$ regardless of what percentage, if any, of their funding comes from donations. ${ }^{73}$ At the same time, other organizations that might be financed by donations, but do not qualify as charities under section 501(c)(3), do not benefit from the unemployment tax exemption. ${ }^{74}$ Second, the concern about possible income transfers to other employers does not warrant ex-

69. See supra note 46.

70. This generation's workers, more of whom are employed by nonprofit organizations than ever before, see supra note 8 , finance social security benefits for an earlier generation of workers, most of whom were employed by for-profit firms.

71. In the Senate Report, the only phrase that gave any explanation as to why charitable organizations should not have to assist in financing the unemployment costs of for-profit firms was that $\S 501$ (c)(3) organizations are "often dependent upon charitable contributions." S. REP. No. 752, supra note 40, reprinted in 1970 U.S. CODE CoNG. \& AD. NEws, at 3618.

72. 26 U.S.C. $\S 3306(c)(8)(1982)$.

73. Not all $\S 501(\mathrm{c})(3)$ organizations are financed exclusively or even primarily by donations. Many, such as hospitals and schools, receive a substantial portion of their funding from charging for the goods or services they provide. See Hansmann, Role, supra note 9, at 840-41 (distinguishing between donative and commercial nonprofit organizations).

74. Not all organizations that receive donations are $\S 501$ (c)(3) organizations. The tax deduction for charitable contributions is not defined in terms of $\$ 501$ (c)(3). A taxpayer may deduct contributions, up to a limit of $50 \%$ of the taxpayer's taxable income, to certain organizations, many of which will also qualify as tax-exempt under $\S 501(c)(3)$. I.R.C. $\$ 170(b)(1)(A)$ (1982). Contributions to certain other organizations are also tax deductible, provided that these contributions do not exceed $20 \%$ of the taxpayer's income. Id. $\S 170(\mathrm{~b})(1)(\mathrm{B})$. Among this second group of organizations are organizations not entitled to $\S 501$ (c)(3) status, such as organizations of war veterans, fraternal societies, and nonprofit cemetery companies. Id. $\S \S 170(\mathrm{c})(3)-(5)$. These organizations, many of which may receive substantial funding from donations, do not have the option of electing the reimbursement method of paying state unemployment insurance costs, and must also pay the federal unemployment insurance tax. See 26 U.S.C. $\$ 3306$ (c) (1982) (exemption based on $\S 501$ (c)(3) status). Furthermore, other organizations that do not qualify under either $\S 170$ or any category of $\S 501$ may still receive donations, but they are not exempt from unemployment taxes. 
emption from the federal unemployment insurance tax, which covers the administrative expenses of the program. Since each employee benefits from the protection guaranteed by the unemployment compensation program ${ }^{78}$ the administrative costs should be financed according to the number of employees benefitting from the program. ${ }^{78}$ Third, a truly separate self-insurance program for section 501(c)(3) employers should still be consistent with the basic tenets of unemployment insurance. In departing from the principle of employer-financed reserve funds and requiring employers only to reimburse the unemployment funds, Congress created a subsidy, not a self-insurance program.

The special provisions governing section 501(c)(3) employers, implemented to avoid an insignificant potential transfer, in fact create a much greater subsidy in the other direction. Undermining the basic premises of the program, the exemptions also create unfair competitive advantages.

\section{Unfair Competitive Advantages}

Concerns about unfair competitive advantages have structured the unemployment insurance program since its inception. ${ }^{77}$ The federal program, imposing a mandatory federal tax that could be offset by state unemployment tax payments, was specifically designed to eliminate the competitive advantages that would follow if only a few states imposed unemployment taxes. ${ }^{78}$ Congress anticipated at the outset that state programs would closely follow the structure of the federal program in order to avoid competitive disadvantages ${ }_{2}^{79}$ in fact, states have rarely extended unemployment coverage unless federal coverage was first extended. ${ }^{80}$ The competitive advantages resulting from variations in the unemployment in-

75. Although not all employees will collect unemployment compensation, each benefits from the assurance provided, and from the fact that individual provisions for unemployment income are not necessary. The objective of unemployment insurance is not only to provide support, security, and dignity for the unemployed worker, but also to "give to the employed workman a sense of security that that would be done." I. RuBinow, The Quest For SECuRITY 419 (1934), quoted in G. FriedMAN, supra note 12 , at 39 .

76. If one assumes "that the cost of serving high-wage and low-wage employers is about the same, the benefit-received norm would dictate . . . a flat amount for each employee covered." J. BECKER, supra note 15 , at 118 .

77. "The initial purpose in the federal unemployment tax ... was to enable states to enact unemployment insurance laws without fear that the cost would place their employers at a disadvantage in interstate competition." W. HABER \& M. MURRAY, supra note 20, at 346.

78. Imposition of a federal unemployment tax with allowance for state tax credits "[made] it possible for every state to set up an unemployment compensation plan financed by a payroll tax up to $2.7 \%$ without placing its industries at a disadvantage as compared with those in other states." $\mathrm{E}$. BurNs, supra note 20 , at 59 .

79. Congress expected that, during the first three years of the program, state tax rates would increase at the same pace as the federal tax rates. Id. at 59-60.

80. See M. Murray, Proposed Federal. Unemployment Insurance Amendments 6 (1966). 
surance tax ratings were viewed as one of the merits of experiential state ratings. Because firms with poor unemployment records would face higher marginal costs as a result of higher unemployment insurance rates, they would lose a portion of their market share, and perhaps eventually be forced out of business. Although fundamental to the unemployment insurance program's structure, these concerns about competitive tax advantages have been ignored in the context of the exemption for section 501(c)(3) employers.

Because their nonprofit status accords them preferential treatment under many laws, ${ }^{81}$ nonprofit organizations may obtain an unfair competitive advantage over profit-motivated firms. Prompted by the expansion of nonprofit organizations into active business enterprises ${ }^{82}$ unrelated to their exempt purposes, and by concerns about issues of horizontal equity ${ }^{83}$ and competitive advantages, Congress enacted the Unrelated Business Income Tax in 1950. ${ }^{84}$ The fairness concerns that led to the Unrelated Business Income Tax apply also to the unemployment insurance exemption. Nevertheless, in implementing the unemployment insurance program, Congress completely ignored the principles underlying the Unrelated Business Income Tax.

Some commentators have claimed that the Unrelated Business Income Tax is unnecessary, arguing that exempting charities from taxation does not lead to unfair competition. ${ }^{85}$ Their arguments, however, do not apply

81. See Hansmann, Role, supra note 9, at 836-37.

82. The tax on unrelated business income does not apply to "passive" income, such as dividends, interest, royalties, or rents. 26 U.S.C. $\$ 512$ (1982). The distinction between passive and active income stems from a congressional belief that "passive" income should not be taxed because "investment-producing incomes of these types have long been recognized as a proper source of revenue for educational and charitable organizations." S. REP. No. 2375, supra note 45, reprinted in 1950 U.S. Code Cong. \& AD. NEws, at 3083.

83. Horizontal equity is the notion that similarly situated entities should be assessed equal taxes. For a discussion of horizontal equity, see R. MusGrave \& P. MusGrave, supra note 44, at 232-33.

84. Revenue Act of 1950 , Pub. L. No. 81-814, tit. III, $\S 301$, reprinted in 1950 U.S. CoDE Cong. \& AD. News 479, 528-35 (codified as amended at 26 U.S.C. $\S \S 511-515$ (1982)). Noting that "It]he problem at which the tax on unrelated business income is directed . . . is primarily that of unfair competition," the House Report accompanying the enactment of the Unrelated Business Income Tax observed that the tax exemption granted to certain organizations "enables them to use their profits tax-free to expand operations, while their competitors can expand only with the profits remaining after taxes." S. REP. No. 2375, supra note 45, reprinted in 1950 U.S. CoDE CoNG. \& AD. NEws, at 3081 .

85. See Bittker \& Rahdert, supra note 42, at 322-26; Klein, Income Taxation and Legal Entities, 20 UCLA L. REv. 13, 61-68 (1972); Comment, Preventing the Operation of Untaxed Business by Tax-Exempt Organizations, 32 U. ChI. L. Rev. 581, 591-92 (1965); Note, Colleges, Charities, and the Revenue Act of 1950, 60 YALE L.J. 851, 875-76 (1951) [hereinafter cited as Note, Colleges, Charities]. But see Rose-Ackerman, supra note 61, at 1021 (arguing that the income tax exemption does result in competitive advantage in certain circumstances); Note, The Macaroni Monopoly: The Developing Concept of Unrelated Business Income of Exempt Organizations, 81 HaRv. L. REv. 1280,1282 (1968) (arguing that "the fast accumulation of capital made possible by tax-free profits is an advantage in any field") [hereinafter cited as Note, The Macaroni Monopoly].

The impact of a charitable organization's unfair competitive advantages in an unrelated business 
to the unemployment tax exemption. The preferential treatment of section 501(c)(3) organizations under the unemployment insurance tax does create a problem of unfair competition.

If the income tax is viewed as a tax on pure profits, ${ }^{86}$ imposition or removal of the tax will not change a profit-maximizing firm's production decisions. ${ }^{87}$ In contrast, the unemployment insurance tax is an excise tax on the firm's payroll. Imposition of this tax will affect production decisions, because it effectively raises the cost of one factor of production, labor. ${ }^{88}$ This change in the relative prices of inputs alters the firm's optimal mix of factor inputs ${ }^{89}$ and increases the firm's marginal $\cos ^{90}$ of production. These changes will cause the firm to cut back on production, to the point where the firm's new, higher marginal cost now equals marginal

will be somewhat limited, since a charity engages in an unrelated business not to maximize profits in that business, but rather to obtain funds for the organization's primary, exempt activity. See Bittker \& Rahdert, supra note 42, at 323-26; Rose-Ackerman, supra note 61, at 1029. Thus, even with a subsidy, the organization would limit its expansion in the unrelated business because capital invested in the unrelated business is capital diverted from the organization's exempt purposes. The unemployment insurance tax exemption, however, subsidizes the charitable organization's primary, as well as its unrelated, business, and thus will not be subject to the same self-limiting trade-off between investment in the exempt or in the unrelated business.

86. Traditional economic theory suggests that "[a] tax on profits does not change the position of the marginal revenue and cost schedules; hence it does not change the position of optimum price and output." R. Musgrave, The Theory of Pubuic Finance 277 (1959); see also Note, Colleges, Charities, supra note 85, at 875-76 (arguing that "the income tax is not an element in the cost of production and should have no effect" on pricing, although nonprofit firms may engage in uneconomic price-cutting). Musgrave notes, however, that "the theoretical case is far from conclusive," R. MusGRAVE, supra, at 287; under certain circumstances imposition of the tax will affect price and output. Id. at 278-87. See also Rose-Ackerman, supra note 61, at 1023 (although "[e]conomically oriented legal commentators" dismiss theory that nonprofits may possess price-cutting advantage, such argument ignores possibility that nonprofits may affect market prices without "resorting to overtly predatory behavior"); Note, The Macaroni Monopoly, supra note 85, at 1281-82 \& nn.11-12 (arguing that although traditional economic theory suggests profits tax affects neither output nor prices, it has not been empirically determined whether charities may obtain unfair competitive advantages in unrelated businesses from an ability to engage in price cutting, or whether advantages are due solely to ability to accumulate capital faster).

87. The level of production that maximizes pre-tax profits will also maximize the after-tax profits. See Samuelson, Tax Deductibility of Economic Depreciation to Insure Invariant Valuations, 72 J. Pol. EcoN. 604, 605 (1964) (arguing deductibility of interest from taxable income does not affect rational decisionmaker's decision to borrow). One condition of Samuelson's theorem is that the tax rate be uniform over time. To the extent that the firms' income and expenses do not always match, thus distorting income and tax rates, the income tax is an excise tax on capital, imposition of which will affect the firm's optimal mix of factor inputs.

88. The tax was imposed as a payroll tax on employers in recognition of the fact that unemployment costs are a cost of production and should be internalized. See supra note 4 and accompanying text.

89. See J. Hirschleifer, Price Theory and Application 419-28 (2d ed. 1980) (discussing optimal mix of inputs, which is derived from determination of optimal relative factor proportions and determination of most profitable level of production).

90. Marginal cost is the additional increment of cost incurred in producing the last unit of goods. Marginal revenue is the additional increment of revenue resulting from the sale of the last unit produced. A firm's profit-maximizing level of output is that level where marginal revenue equals marginal cost. See id. at 290. 
revenue. $^{01}$ Because the unemployment tax properly internalizes costs, ${ }^{82}$ imposing the tax shifts production and factor employment from a nonoptimal level to the optimal level.

Exempting only certain firms within an industry from the unemployment tax will lower the marginal cost of production for those firms and thus increase their profit-maximizing level of production. Because certain costs of production, the costs of unemployment, are borne externally, this higher level of production by charitable organizations represents an inefficient allocation of resources. If charitable organizations increase the total industry supply beyond the profit-maximizing level of for-profit firms, certain for-profit firms could be squeezed out of the market, or inhibited from entering it. ${ }^{93}$ Aided by this competitive advantage created by the unemployment tax exemption, charitable organizations could thus displace their for-profit competitors. ${ }^{94}$

Giving organizations a competitive advantage by reducing their unemployment tax rates might result in a more efficient allocation of society's resources if, for example, the organizations qualified for the reduced tax rates based on past employment experience. ${ }^{95}$ The competitive advantage resulting from this preferential tax treatment of charitable organizations,

91. This dynamic will occur unless either demand or supply is wholly inelastic, in which case there will be no reduction in output, although price will change. See R. Musgrave \& P. MusGrave, supra note 44 , at $268-86$.

92. A basic premise of the unemployment tax is that

[t]he social and human costs of irregular employment should properly be charged against and compensated by each employing unit. Only in this way can consumers be assured that a low price is not a misleading and parasitic price, and that the competitive (or other) system is really functioning in the public interest.

W. HABER \& M. MURRAY, supra note 20, at 341 (quoting Raushenbush, The Wisconsin Idea: Unemployment Reserves, ANNALs, Nov. 1933, at 65, 72-73 (Nov. 1933).

93. Cf. Hansmann, Rationale for Exempting, supra note 9, at 76-77, 80-82 (viewing corporate income tax as an excise tax on capital and examining the effect of tax exemption on a market consisting of for-profit and nonprofit firms); Rose-Ackerman, supra note 61, at 1022-36 (discussing conditions under which the charitable income tax exemption creates unfair competitive pricing advantages).

94. Charitable organizations will benefit from this advantage unless they face absolute constraints in another area. For example, if the organization were absolutely capital-constrained, it would probably be unable to expand, unless it received some other very substantial subsidy that enabled the firm to shift its factor mix significantly. Absent such absolute constraints, however, the firm will benefit from the competitive advantage of lower after-tax marginal costs.

Depending on other constraints facing the subsidized firm, the competitive advantage may serve simply to lessen the impact of a pre-existing competitive disadvantage. For example, the income tax exemption may not fully compensate for the disadvantage resulting from the higher capital costs faced by nonprofit organizations. See supra note 61 . The unemployment tax exemption probably does not completely eliminate the remaining competitive disadvantage. Nonetheless, the unemployment tax exemption will diminish the charitable organization's disadvantage. The exempt organization will thus occupy a larger share of the market than it would have without the preferential treatment.

95. The proposition that a competitive advantage resulting from experience rating allocates resources efficiently is premised on the assumption that unemployment compensation is an ordinary and necessary cost of doing business that should be internalized and reflected in the prices of goods and services. To the extent that the experience rates create tax incentives for firms to retain employees past the point at which it would be more profitable to let them go, however, the experience rating system distorts the market, resulting in an inefficient allocation of resources. 
however, is based not on any efficiency considerations, ${ }^{96}$ but solely on the organization's status. When a profit-motivated organization is in fact more efficient than its nonprofit competitor, granting a subsidy according to nonprofit status will result in an inefficient and inequitable allocation of resources.

\section{CONCLUSION}

"[T] $]$ he development of unemployment compensation requires a philosophical as well as a practical approach." ${ }^{\text {"gz }}$ Charitable organizations have long been recognized as proper recipients of governmental subsidies and special considerations. The law governing unemployment insurance, however, has inappropriately exempted these organizations from the obligations imposed on other employers. The product of an unexamined deference to the traditional exemptions, the preferential treatment accorded charitable organizations under the Federal Unemployment Tax Act ignores considerations of fairness and concerns for appropriate allocation of resources.

Congress' 1970 decision that section 501(c)(3) employers should participate in the unemployment insurance program moved the law in the right direction, and evidenced a clearer legislative understanding of the tenets of the program. Nevertheless, the distinctions that persist between charitable organizations and other employers enable the former to "purchase" unemployment insurance at a lower price than the latter do. In so doing, the Federal Unemployment Tax Act creates a subsidy for charities that is financed in part by the charities' for-profit competitors. Because unemployment insurance is an ordinary and necessary cost of doing business, and the subsidy of charitable organizations' ordinary business costs gives those organizations an unfair competitive advantage over for-profit firms without efficiently promoting any clear social goals, Congress should eliminate this preferential treatment.

-Amy L. Henrich

96. In fact, the exemption creates inefficiencies. See supra text accompanying notes 88-94.

97. Malisoff, supra note 14 , at 258. 